\title{
Pengaruh Faktor Ekonomi Makro Terhadap Stock Return Pada Indeks Saham LQ45
}

\author{
Candy \\ Universitas Internasional Batam \\ candy.chua@uib.ac.id \\ Anton Winardy \\ Universitas Internasional Batam \\ antonwinardy11@gmail.com
}

\begin{abstract}
Abstrak
Penelitian ini dilakukan untuk menganalisa pengaruh variabel-variabel ekonomi makro, yaitu inflasi, suku bunga, nilai tukar, harga minyak dunia, produk domestik bruto, ekspor, dan impor terhadap stock return perusahaan yang terdaftar di indeks saham LQ45. Sampel dari penelitian ini adalah 79 perusahaan yang pernah terdaftar di LQ45 selama periode Februari 2012 sampai dengan Januari 2017. Metode analisis data yang digunakan adalah regresi panel. Hasil penelitian menunjukkan bahwa inflasi, suku bunga, nilai tukar, produk domestik bruto, ekspor, dan impor berpengaruh signifikan terhadap stock return. Hasil penelitian juga menunjukkan harga minyak dunia tidak berpengaruh signifikan terhadap stock return.
\end{abstract}

Kata Kunci Indeks Saham, Ekonomi Makro, dan Stock Return

\section{PENDAHULUAN}

Pasar modal diartikan sebagai suatu pasar jual beli untuk berbagai instrumen keuangan, seperti surat utang atau obligasi, ekuitas atau saham, reksadana, instrumen derivatif serta instrumen-instrumen yang lain. Pasar modal merupakan salah satu sarana bagi perusahaan maupun institusi lain untuk mencari dana atau modal dari para investor dan sebagai suatu tempat untuk mendukung kegiatan berinvestasi. Sehin gga pasar modal disimpulkan sebagai sarana untuk memfasilitasi kegiatan jual-beli dan kegiatan lainnya yang bersangkutan (Martalena \& Malinda, 2011).

Investasi didefinisikan sebagai penanaman sejumlah modal pada suatu riil aset (emas, properti, tanah dan aset riil lainnya) atau pada aset yang tidak berbentuk riil (surat-surat berharga yang merupakan suatu klaim atas aktiva riil yang dimiliki oleh entitas seperti saham, obligasi, deposito, reksadana, dan surat berharga lainnya). Investasi ini merupakan suatu tindakan yang berorientasi kepada keuntungan yang dapat didapatkan di masa yang akan datang, singkatnya adalah mengharapkan adanya pengembalian dari investasi yang dilakukan di mana pengembalian diartikan sebagai pengembalian dari suatu investasi.

Salah satu instrumen keuangan yang diperdagangkan di pasar modal adalah saham (stock). Saham didefinisikan sebagai tanda pemilikan seseorang atau badan dalam suatu perusahaan. Saham berwujud selembar kertas yang menerangkan bahwa pemilik kertas adalah pemilik perusahaan yang menerbitkan surat berharga tersebut. Porsi kepemilikan ditentukan oleh seberapa besar pernyataan yang ditanamkan di perusahaan tersebut. Saham ini merupakan salah satu investasi instrumen keuangan yang menarik karena dapat memberikan pengembalian tinggi namun juga berisiko tinggi.

Investor melakukan investasi untuk mendapatkan keuntungan dengan mendapatkan dividen yaitu berupa sejumlah uang yang dibayar secara periodik kepada investor ataupun capital gain yang merupakan selisih antara harga saham pada saat pembelian dengan harga saham pada saat penjualan. Namun dalam berinvestasi tidak ada satu pun investasi yang menjaminkan keuntungan terutama investasi pada saham yang memiliki risiko tinggi. Unsur risiko ada dalam setiap investasi maka investor harus melakukan berbagai analisis terhadap faktor-faktor yang dapat mempengaruhi fluktuasi suatu nilai saham. Analis is 
tersebut akan mendapatkan gambaran yang lebih tentang kemampuan suatu perusahaan untuk terus berkembang atau tidak.

Kinerja pasar saham Indonesia dicerminkan oleh kinerja dari Indeks Saham Harga Gabungan (IHSG) di Indonesia. Salah satu faktor utama yang mempengaruhi perekonomian negara termasuk Indonesia yang berdampak langsung terhadap pasar saham adalah faktor makroekonomi. Pengaruh makroekonomi telah menjadi sebuah pengukuran bagi para investor untuk melihat kondisi pasar saham yang akan diinvestasi. Berikut merupakan grafik harga saham dari IHSG di dalam periode dari 1 Januari 2012 sampai ke 31 Desember 2017 di mana menunjukkan bahwa harga saham mengalami pergerakan yang fluktuatif sepanjang tahun.

Indeks Harga Saham Gabungan Indonesia

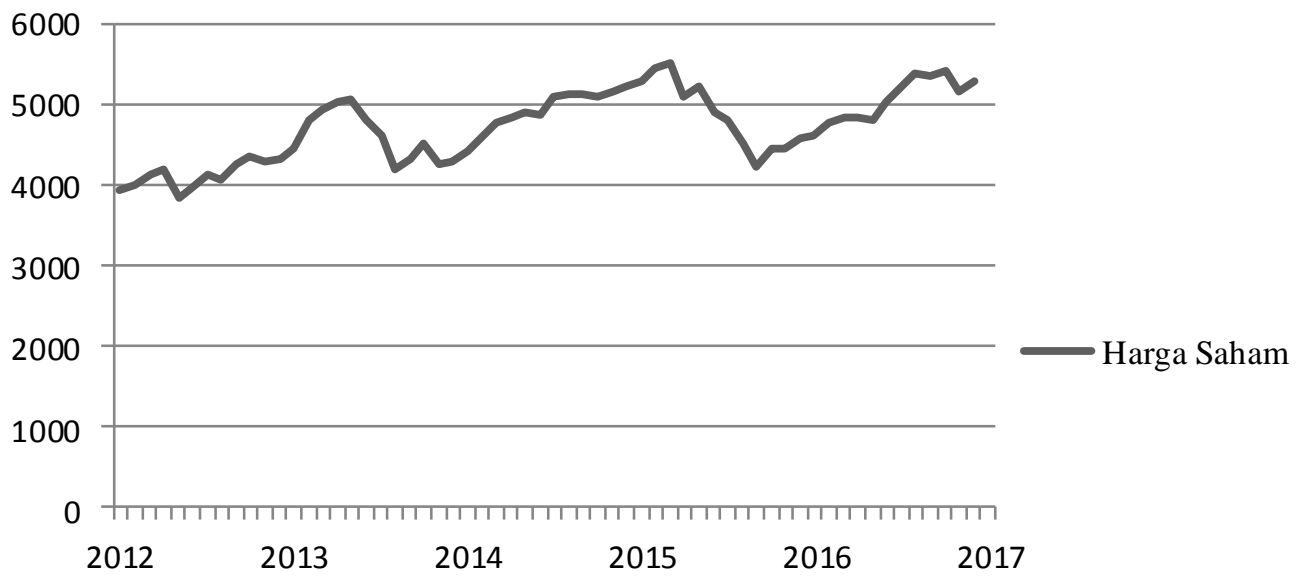

Sumber: Yahoo Finance (2017)

Gambar 1 Grafik Indeks Harga Saham Gabungan (IHSG) Indonesia Periode 1 Januari 2012-31 Desember 2017

Gambar 1 menunjukkan pergerakan harga saham yang fluktuatif disebabkan oleh beberapa faktor. Salah satu faktor yang memberikan dampak yang jelas adalah faktor makroekonomi. Perubahan makroekonomi di Indonesia tentu akan mempengaruhi perekonomian nasional serta seluruh industri. Contohnya inflasi yang tinggi dan melemahnya rupiah akan membuat banyak industri mengalami goncangan, produksi yang menurun akibat harga-harga bahan baku yang terus naik yang mengakibatkan menurunnya tingkat laba. Penurunan tingkat laba tentu akan memberikan dampak pada turunnya harga saham di industri tersebut karena dividen yang akan diterima oleh para pemegang saham akan menurun sehingga banyak investor yang akan menarik investasi mereka. Naiknya suku bunga akan membuat para investor lebih tertarik untuk berinvestasi dalam bentuk tabungan di bank daripada investasi di pasar modal. Penurunan harga saham pada industri akan berdampak juga pada turunnya nilai Indeks Harga Saham Gabungan (IHSG) pada Bursa Efek Indonesia (BEI) (Astuti et al., 2016).

IHSG pada tahun 2013 dan 2015 terlihat jelas dalam Gambar 1 menunjukkan bahwa terjadinya penurunan harga saham yang tajam pada nilai Indeks Harga Saham Gabungan (IHSG) pada Bursa Efek Indonesia (BEI). Pada tahun 2015 terlihat jelas bahwa penurunan harga saham perusahaan yang terdaft ar di BEI itu diiringi oleh beberapa masalah makroekonomi yang terjadi dalam tahun tersebut.

Krisis ekonomi di Indonesia pada tahun 2015, yang dibuktikan oleh pelemahan kurs rupiah yang menembus angka Rp14.000 per USD pada tahun 2015 menjadi sebuah ancaman yang mengerikan bagi Indonesia. Angka itu secara ekonomi mencerminkan bahwa banyak investor yang berpindah dari Indonesia ke negara lain. Konsekuensinya adalah pembangunan-pembangunan nasional yang melibatkan investasi asing dapat terganggu (Dakwatuna, 2015). 


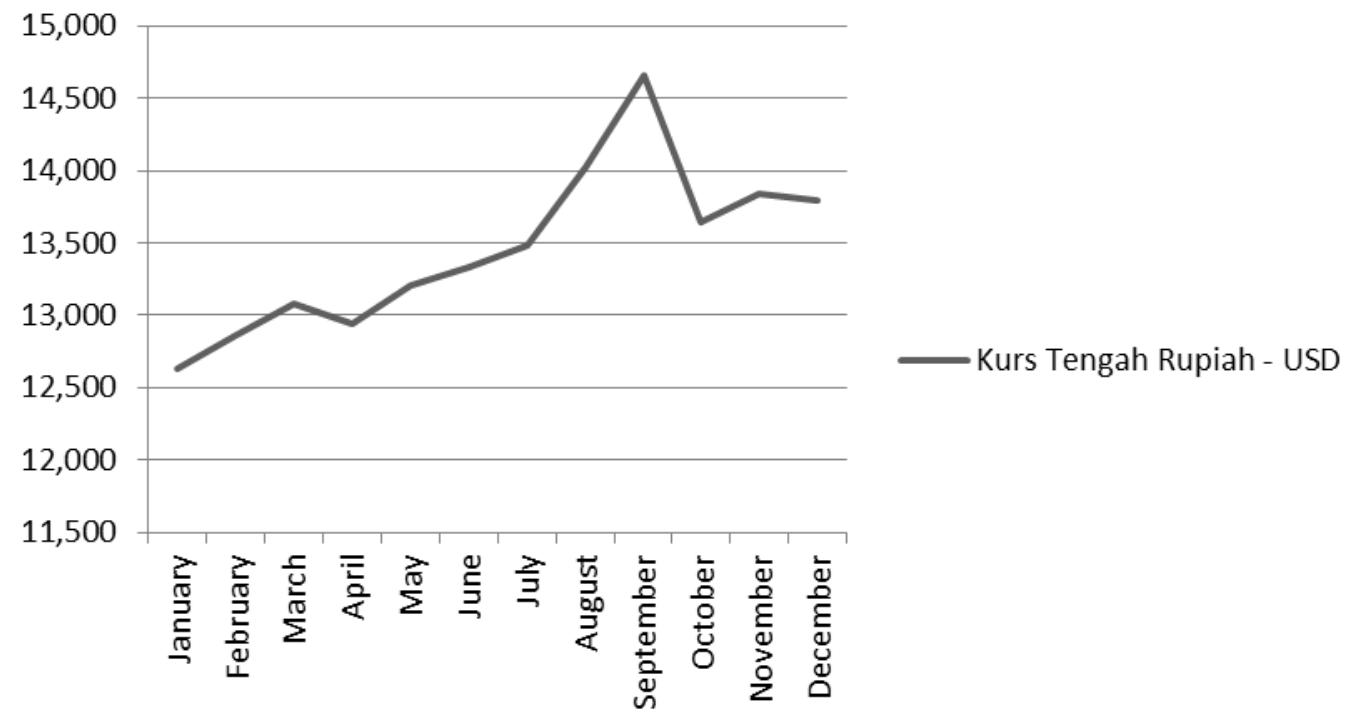

Sumber: Bank Indonesia (2017)

Gambar 2 Harga Nilai Tukar Rupiah terhadap USD

Periode 1 Januari 2015-31 Desember 2015

Nilai tukar pada tahun 2015 juga mengalami penurunan harga minyak dunia yang tajam dengan penurunan sebanyak 35\% sepanjang tahun 2015 yang merupakan hal yang paling mengerikan pada seluruh pasar saham di berbagai negara terutama pada sektor migas. Sektor migas pada Indonesia secara drastik mengalami penurunan oleh karena turunnya harga minyak dunia (Sindonews, 2016). Shell memecat 6.500 pekerja dan perusahaan minyak Italia memecat 8.800 pekerja dikarenakan oleh profitabilitas yang turun tajam dengan pemecatan begitu secara langsung juga akan mengurangi daya beli masyarakat karena meningkatnya tingkat pengangguran yang tinggi (Merdeka, 2015).

Nilai tukar rupiah menembus angka Rp14.000 terhadap USD dan juga harga minyak dunia yang menurun 35\% sepanjang tahun 2015 jelas memberikan dampak yang cukup terlihat pada Gambar 1 di mana menunjukkan angka harga saham yang menurun drastis pada tahun 2015 di IHSG. Hal demikian juga terjadi pada sektor saham yang memiliki likuiditas terbaik di Indonesia yaitu indeks LQ45 yang terbilang sektor saham yang memiliki likuiditas terbaik serta kapitalisasi pasar yang tertinggi di antara saham lainnya.

Indeks LQ45 adalah indeks yang terdiri dari 45 emiten saham pilihan yang memiliki kriteria tertentu. Pergerakan indeks ini juga didasarkan pada perhitungan dari 45 saham, yang diseleksi melalui beberapa kriteria pemilihan. Selain penilaian atas likuiditas, seleksi atas saham-saham tersebut mempertimbangkan kapitalisasi pasar. Indeks LQ 45 berisi 45 saham yang disesuaikan setiap enam bulan (setiap awal bulan Februari dan Agustus). Dengan demikian saham yang terdapat dalam indeks tersebut akan selalu berubah (May, 2017).

Berdasarkan fenomena-fenomena yang menghasilkan berbagai kesimpulan di atas, dapat disimpulkan bahwa hubungan antara makroekonomi dengan pengembalian saham sangat erat namun belum tentu dapat diberlakukan untuk segala kondisi. Investasi pada saham harus memperhatikan kemampuan internal perusahaan, diwajibkan juga untuk menganalisa variabel makroekonomi yang memiliki hubungan erat terhadap fluktualitas harga saham. Penelitian ini menggunakan sejumlah variabel faktor makroekonomi berupa inflasi, suku bunga, nilai tukar, harga minyak dunia, produk domestik bruto, ekspor, dan impor. Berdasarkan uraian di atas, maka penulis akan melakukan penelitian "Pengaruh Faktor Ekonomi Makro Terhadap Stock Return Pada Indeks Saham LQ45".

\section{LANDASAN TEORI}

\section{Stock Return}

Pengembalian saham dijadikan sebagai ukuran dalam dunia bisnis. Nilai dari suatu pengembalian dari saham menandakan atau mencerminkan kondisi kinerja perekonomian suatu negara dalam periode tertentu. Negara yang sedang berkembang sangat memperhatikan pada kinerja saham karena saham 
adalah salah satu komponen yang sangat mempengaruhi kinerja ekonomi suatu negara. Disimpulkan bahwa pergerakan saham berpengaruh signifikan terhadap pergerakan ekonomi (Tan, 2010).

\section{Pengembangan Hipotesis}

Nijam et al. (2015), Nisha (2015), Abbas et al. (2014), Haque dan Sarwar (2012), menunjukkan bahwa inflasi memiliki hubungan signifikan negatif terhadap pengembalian saham. Hal ini dikarenakan meningkatnya tingkat inflasi akan memperketat kebijakan moneter dan fiscal. Tingkat inflasi yang tinggi juga akan menyebabkan kenaikan tingkat suku bunga dimana akan para investor akan mengalokasikan dana investasinya ke deposito sehingga pengembalian saham menurun.

Balagobei (2017), Tiryaki et al. (2017), Laichema dan Obwogi (2015), Pinjaman dan Aralas (2015), Kibria et al.(2014), Ouma dan Muriu (2014), Lekobane et al. (2014), dan Tangjitprom (2012) menunjukan bahwa hasil penelitiannya mempunyai hubungan signifikan positif antara inflasi dan pengembalian saham yang menjelaskan bahwa pengembalian yang bertambah akan diikuti oleh kenaikan inflasi yang meningkatkan biaya kehidupan serta daya beli pada investasi.

Tripathi dan Kumar (2014) meneliti hubungan antara inflasi dengan pengembalian saham pada pasar saham BRICS menemukan bahwa pada pasar saham India dan Cina terdapat hubungan signifikan positif antara pengembalian dengan inflasi dikarenakan oleh pengembalian merupakan refleksi dari inflasi. Namun ternyata pada pasar Brazil dan Russia tidak sedemikian rupa oleh karena tingginya inflasi akan menaikan juga suku bunga dimana investor akan memindahkan dananya dari investasi saham ke investasi perbankan sehingga harga saham menurun.

Barakat et al. yang meneliti pada pasar saham Tunisia dan Mesir juga menemukan hasil yang berbeda dimana Tunisia memiliki hubungan negatif antara pengembalian saham dengan inflasi sedangkan pada Mesir memiliki hubungan positif antara pengembalian saham dengan inflasi. Penelitian dari Sutrisno (2017), Srichaikul et al. (2018), Khan et al. (2017), Salamat et al. (2017), Linck dan Decourt (2016), Safitri dan Kumar (2014), Tangjitprom (2012), Zhu (2012), dan Bellalah et al. (2012) menemukan bahwa inflasi tidak memiliki pengaruh signifikan terhadap pengembalian saham di sampel penelitiannya masingmasing. Namun inflasi dapat memiliki pengaruh yang berbeda pada sektor yang dan dapat juga berdampak positif atau negatif pada periode tertentu. Berdasarkan hasil penelitian sebelumnya, maka dapat dirumuskan hipotes is sebagai berikut:

$\mathrm{H}_{1}=$ Inflasi berpengaruh signifikan negatif terhadap stock return perusahaan yang terdaftar di LQ45.

Sutrisno (2017), Balagobei (2017), Tiryaki et al. (2017), Oshaibat dan Majali (2016), Latha et al. (2016), Linck dan Decourt (2016), Barakat et al. (2016), Laichena dan Obwogi (2015), Hussain et al. (2014), Haque dan Sarwar (2012), dan Tangjitprom (2012) menunjukkan hubungan signifikan negatif antara suku bunga dengan pengembalian saham dikarenakan semakin meningkatnya suku bunga, para investor akan berpindah ke investasi sekuritas finansial sehingga harga saham menurun dan berdampak pada pengembalian saham. Selain itu semakin tingginya tingkat suku bunga akan meningkatkan biaya bunga pinjaman sehingga akan mengurangi profitabilitas perusahaan.

Nisha (2015) dan Nijam et al. (2015) tidak sependapat dengan pernyataan-pernyataan di atas dimana terdapat bukti pada penelitiannya yang menunjukkan adanya hubungan signifikan positif antara suku bunga dengan harga saham dan pengembalian saham pada pasar saham. Hasil penelitian ini diperkuat oleh Lim dan Sek (2014) yang melakukan penelitian tentang pengaruh nilai tukar terhadap pengembalian saham pada pasar saham di Indonesia, Korea, Filipina, dan Thailand. Kenaikan suku bunga akan menarik lebih banyak investor luar negeri untuk menginvestasi dalam pasar perbankan.

Lekobane et al. (2014) menunjukkan bahwa long term interest rate memiliki hubungan signifikan negatif dengan harga saham dikarenakan long term interest rate menekan dan memperlambat kegiatan ekonomi dan keuntungan perusahaan sehingga berdampak pada harga saham. Short-term interest rate memiliki hubungan signifikan positif dengan harga saham dikarenakan short-term interest rate akan menyebabkan dana masuk ke investasi jangka pendek sehingga mengurangi investasi pada pasar saham.

Srichaikul et al. (2018), Khan et al. (2017), Salamat et al. (2017), Ismail et al. (2016), Singh (2014), Safitri dan Kumar (2014), Murthy et al. (2014), Ouma dan Muriu (2014), dan Bellalah et al. (2012) menunjukkan tidak adanya hubungan signifikan antara suku bunga dengan pengembalian saham pada pasar saham. Berdasarkan hasil penelitian sebelumnya, maka dapat dirumuskan hipotesis sebagai berikut: $\mathrm{H}_{2}$ = Suku bunga berpengaruh signifikan negatif terhadap stock return perusahaan yang terdaftar di LQ45. 
Zhu (2012) menunjukkan adanya hubungan signifikan positif antara nilai tukar terhadap pengembalian saham yang ditunjukkan bahwa nilai tukar mempengaruhi pengembalian saham sektor energi pada tingkat signifikan $1 \%$ di pasar saham Shanghai. Nilai koefisien $(0,060502)$ menunjukkan bahwa nilai tukar CNY /USD memiliki hubungan positif dengan pengembalian saham sektor energi di SEE dimana pengembalian saham sektor energi meningkat 0,060502 poin sebagai mata uang Cina (CNY) disusutkan terhadap dolar AS 1 poin.

Penelitian Haque dan Sarwar (2012) menunjukkan bahwa adanya hubungan signifikan positif antara nilai tukar dengan pengembalian saham dikarenakan bila nilai mata uang domestik meningkat mencerminkan bahwa sektor pasar saham di negara tersebut kuat dan terjadi peningkatan pada harga saham. Lim dan Sek (2014) memperkuat penelitian di atas dengan meneliti di pasar saham Asia yang menunjukkan adanya hubungan signifikan positif antara nilai tukar dengan pengembalian saham dikarenakan 4 pasar negara di Asia adalah negara berkembang sehingga dengan depresiasi nilai mata uang domestik mereka akan menurunkan juga harga pada pasar saham Asia di pasar internasional.

Hasil penelitian yang sama juga ditunjukkan oleh Balagobei (2017), Khan et al. (2017), Tiryaki et al. (2017), dan Nijam et al. (2015), Kibria et al. (2014), Pinjaman dan Aralas (2015), Nisha (2015) dan Zhu (2012) yang meneliti pengaruh variabel makroekonomi terhadap pengembalian saham. Jika niali mata uang domestik menguat akan mengurangi biaya impor untuk para peru sahaan yang mendapatkan bahan baku dari luar negeri sehingga meningkatkan profitabilitas dan pengembalian saham dari perusahaan tersebut.

Tangjitprom (2012) memiliki hasil penelitian yang berbeda dimana terdapat hubungan signifikan negatif antara nilai tukar terhadap pengembalian saham di pasar saham Thailand. Hal ini dikarenakan oleh menguatnya mata uang asing menurunkan pengembalian saham dari pasar saham Thailand. Singh (2014) juga berpendapat serupa dimana hasil penelitian yang dikaji pada pasar saham India menunjukkan hubungan signifikan negatif antara nilai tukar dengan pengembalian saham.

Safitri dan Kumar (2014) menunjukkan adanya hubungan signifikan negatif antara nilai tukar terhadap pengembalian saham pada pasar saham Indonesia dikarenakan oleh ketika nilai mata uang rupiah meningkat, beberapa biaya dalam melakukan bisnis mendapatkan lebih rendah. Dalam situasi ini, aktifitas perdagangan saham indeks harga saham akan meningkat. Lekobane et al. (2014) melakukan penelitian di pasar saham Botswana di Jordania dimana mendapatkan hasil signifikan negatif antara nilai tukar terhadap pengembalian saham dikarenakan oleh devaluasi mata uang domestik akan ada efek positif pada profitabilitas perusahaan sektor ekspor domestik yang pada akhirnya menyebabkan peningkatan harga saham.

Penelitian Hussain et al. (2014) pada pasar saham Karachi di Pakistan dimana mendapatkan hasil signifikan negatif antara nilai tukar terhadap pengembalian saham dikarenakan depresiasi mata uang domestik atau menguatnya nilai mata uang asing akan meningkatkan biaya energi, biaya impor, dan juga yang lain sehingga memilik efek buruk pada proftabilitas perusahaan. Srichaikul et al. (2018), Sutrisno (2017), Murthy et al. (2017), Laichena dan Obwogi (2015), Ouma dan Muriu (2014), dan Ramanujam dan Leela (2014) menunjukkan hasil yang sejalan dengan penelitian di atas yaitu terjadinya hubungan signifikan negatif antara nilai tukar dengan perngembalian saham.

Gay (2016), Ismail et al. (2016), Abbas et al. (2014), dan Nisha (2015) menunjukkan hasil yang berbeda dengan penelitian-penelitian di atas dimana menunjukkan tidak adanya hubungan signifikan antara nilai tukar terhadap pengembalian saham yang dibuktikan oleh penelitian yang dilakukan di pasar saham. Berdasarkan hasil penelitian sebelumnya, maka dapat dirumuskan hipotesis sebagai berikut:

$\mathrm{H}_{3}=$ Nilai tukar berpengaruh signifikan negatif terhadap stock return perusahaan yang terdaftar di LQ45.

Kang et al. (2014) menunjukkan adanya hubungan signifikan negatif antara harga minyak dengan pengembalian saham pada pasar saham U.S. Hal ini disebabkan oleh kenaikan harga minyak akan meningkatkan pengembalian untuk negara pengekspor minyak namun akan menurunkan pengembalian saham pada pasar saham di negara pengimpor minyak seperti U.S dikarenakan investor akan memindahkan dana investasinya ke sektor perminyakan di negara pengekspor minyak. Penelitian Tiryaki et al. (2017), Khan et al. (2016), dan Samontaray et al. (2014) menunjukkan adanya hubungan signifikan positif antara harga minyak dengan pengembalian saham dimana seiringnya kenaikan harga minyak menandakan bahwa permintaan minyak yang meningkat memberikan sinyal bahwa aktifitas ekonomi sedang membaik karena minyak merupakan sumber daya yang penting di berbagai industri.

Penelitian Guliman dan Avenue (2015) menunjukkan adanya hubungan tidak signifikan antara harga minyak dengan pengembalian saham di pasar saham Filipina. Mayoritas pasar saham Filipina terdiri dari perusahaan sektor finansial dimana tidak bergantung pada sektor perminyakan untuk operasionalnya. 
Penelitian tersebut diperkuat oleh Srichaikul et al. (2018), Murthy et al. (2017), Gay (2016), dan Singh (2014) menunjukkan juga adanya hubungan tidak signifikan antara harga minyak dunia dengan pengembalian saham. Berdasarkan hasil penelitian sebelumnya, maka dapat dirumuskan hipotes is sebagai berikut:

$\mathrm{H}_{4}=$ Harga minyak dunia berpengaruh signifikan positif terhadap stock return perusahaan yang terdaftar di LQ45.

Linck dan Decourt (2016), Ismail et al. (2016), Laichena dan Obwogi (2015), Nijam et al. (2015), Lekobane et al. (2014), Ramanujam dan Leela (2014), Monjazeb dan Gohari (2013), Kibria et al. (2014), serta Haque dan Sarwar (2012) meneliti hubungan antara produk domestik bruto terhadap pengembalian saham dimana hasil menunjukkan bahwa antara dua variabel tersebut memiliki hubungan signifikan positif dikarenakan produk domestik bruto yang bertambah akan meningkatkan situasi pasar bisnis termasuk pasar saham dalam suatu negeri. Penelitian Salamat et al. (2017), Pinjaman dan Aralas (2015) menunjukkan bahwa antara dua variabel tersebut memiliki hubungan signifikan negatif.

Penelitian dari Abbas et al. (2014) dan Safitri dan Kumar (2014) menunjukkan hasil yang berbeda dari penelitian-penelitian di atas di mana ditemukan tidak adanya hubungan signifikan antara produk domestik bruto terhadap pengembalian saham yang dikarenakan oleh peningkatan pada produk domestik bruto tidak berarti meningkat pada semua pendapatan dari masyarakat yang menandakan tidak meratanya kesejahteraan kepada penduduk sesuai dengan Teori Pareto atau Teori 80-20. Berdasarkan hasil penelitian sebelumnya, maka dapat dirumuskan hipotesis sebagai berikut:

$\mathrm{H}_{5}=$ Produk domestik bruto berpengaruh signifikan positif terhadap stock return perusahaan yang terdaftar di LQ45.

Penelitian dari Monjazeb dan Gohari (2013), Hussain et al. (2014) serta Samontaray et al. (2014) menunjukkan adanya pengaruh signifikan positif antara ekspor terhadap pengembalian saham. Bertambahnya ekspor dalam suatu negara dapat meningkatkan pendapatan yang dapat didapatkan oleh suatu negara. Semakin banyak pertambahan pada jumlah ekspor maka akan meningkatkan proftabilitas perusahaan yang berbasis ekspor sehingga pembagian dividen dari perusahaan tersebut akan bertambah dan berdampak positif terhadap harga saham dari perusahaan tersebut.

Penelitian tersebut di atas dibantah oleh Zhu (2012) yang menunjukkan adanya pengaruh signifikan negatif antara ekspor terhadap pengembalian saham. Bertambahnya ekspor yang terus -menerus akan meningkatkan kelangkaan dalam sumber daya alam dalam negeri sehingga perusahaan pengekspor harus juga mengimpor bahan baku dari luar negeri yang meningkatkan biaya yang lebih mahal. Oleh karena itu hal tersebut dapat melemahkan keadaan perusahaan yang melakukan kegiatan ekspor ke luar n egeri dalam jumlah besar sehingga harga saham melemah dan tingkat pengembalian saham juga ikut melemah. Penelitian dari Bellalah et al. (2012) menunjukkan hasil yang berbeda dengan penelitian-penelitian di atas yang menunjukkan bahwa ekspor tidak mempunyai hubungan signifikan dengan pengembalian saham. Berdasarkan hasil penelitian sebelumnya, maka dapat dirumuskan hipotesis sebagai berikut:

$\mathrm{H}_{6}=$ Ekspor berpengaruh signifikan positif terhadap stock return perusahaan yang terdaftar di LQ45.

Tiryaki et al. (2017), Hussain et al. (2014), dan Bellalah et al. (2012) menunjukkan adanya pengaruh signifikan positif antar impor terhadap pengembalian saham. Dengan bertambahnya impor dalam negeri, dapat diartikan bahwa adanya kegiatan impor untuk mesin, plantansi, bah an baku, dan segala kebutuhan industri untuk memaksimalkan kegiatan operasional perusahaan yang bergerak diberbagai sektor sehingga meningkatkan kinerja dari perusahaan dan mempengaruhi harga saham untuk meningkat. Zhu (2012) menunjukkan hasil penelitian yang berbeda dengan penelitian di atas dimana ada terjadinya pengaruh tidak signifikan antara impor terhadap tingkat pengembalian saham. Berdasarkan hasil penelitian sebelumnya, maka dapat dirumuskan hipotesis sebagai berikut:

$\mathrm{H}_{7}=$ Impor berpengaruh signifikan positif terhadap stock return perusahaan yang terdaftar di LQ45. 


\section{Model Penelitian}

Berdasarkan model penelitian terdahulu, maka model penelitian disajikan sebagai berikut:

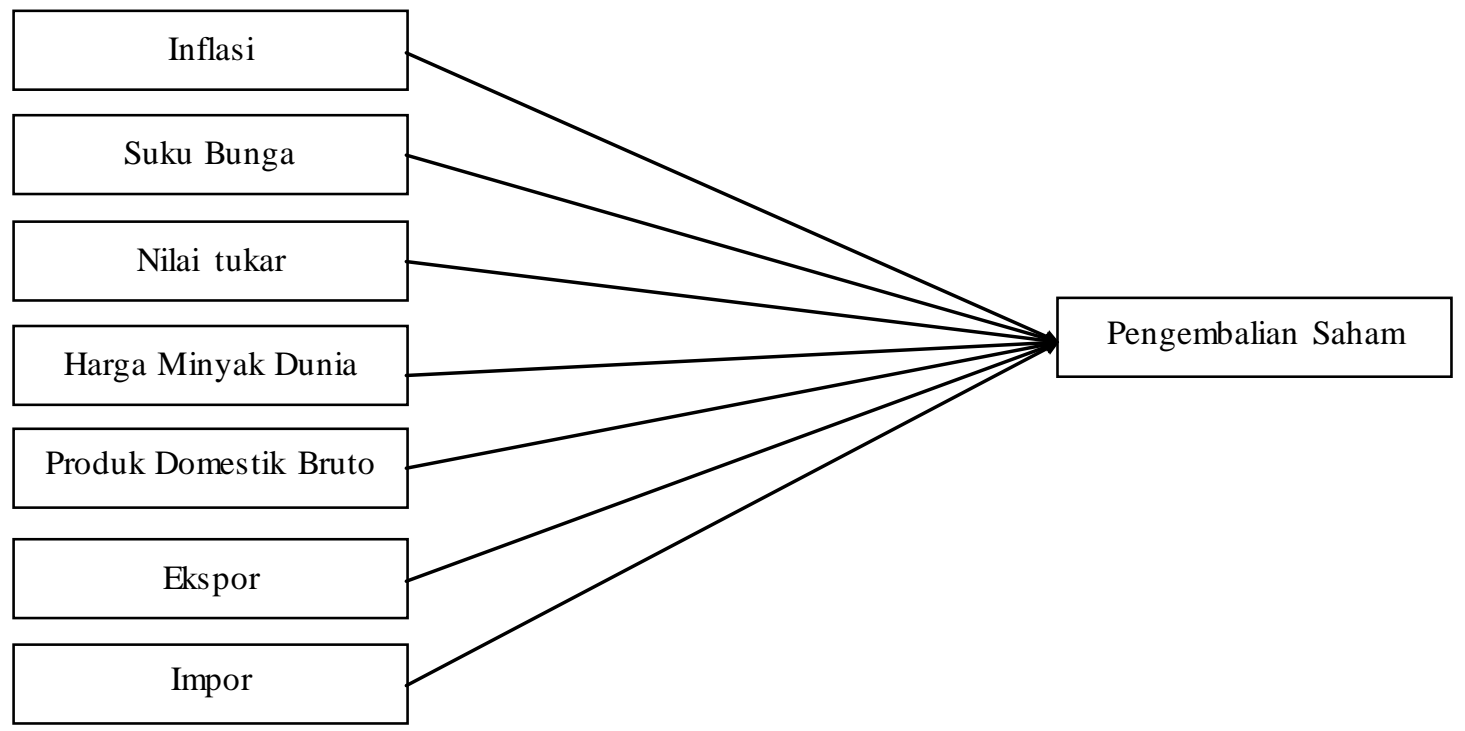

Gambar 3 Model Pengaruh Faktor Ekonomi Makro Terhadap Stock Return

\section{METODOLOGI PENELITIAN}

Penelitian ini merupakan jenis penelitian asosiatif dengan hubungan kausal komparatif di mana terdapat variabel dependen dan variabel independen. Penelitian ini mempunyai sifat deduktif dikarenakan penelitian ini memiliki tujuan untuk menguji hipotesis terhadap ada atau tidaknya hubungan signifikan antara variabel independen dengan variabel dependen. Dilihat dari data yang dikumpulkan, penelitian ini merupakan penelitian kuantitatif karena terdapat perhitungan data penelitian yang berupa angka yang dapat didapatkan dari data-data eksternal yang dipublikasikan kepada umum (Indriantoro \& Supomo, 2013).

Obyek penelitian yang terpilih dalam penelitian ini adalah perusahaan-perusahaan yang terdaftar di LQ45. Metode pemilihan obyek penelitian sampel adalah dengan purposive sampling yang berarti bahwa pemilihan sampel yang dipertimbangkan dan harus mempunyai kriteria-kriteria tertentu. Kriteria dari sampel pada penelitian ini dijabarkan sebagai berikut:

1. Perusahaan yang bersangkutan terdaftar di BEI dan pernah terdaftar di indeks LQ45 sejak periode Februari 2012 hingga Januari 2017.

2. Perusahaan yang tercatat di indeks LQ45 setidaknya selama satu periode dalam satu tahun, yaitu periode Februari-Juli atau Agustus-Januari.

3. Data yang diteliti pada penelitian ini adalah data sekunder. Data tersebut adalah gabungan dari cross sectional dan time series yang disebut data panel (pooled data). Cross sectional adalah suatu studi yang bertujuan untuk mengetahui hubungan komparatif beberapa subjek yang diteliti, sedangkan time series lebih ditekankan pada data penelitian berupa data rentetan waktu (Indriantoro \& Supomo, 2013)

Stock return dari indeks saham perusahaan yang terdaftar di LQ45 dijadikan variabel dependen pada penelitian ini. Sedangkan variabel independen meliputi inflasi, suku bunga, nilai tukar, harga minyak dunia produk domestik bruto, ekspor, dan impor. Variabel dependen didefinisikan sebagai variabel yang disebabkan atau dipengaruhi oleh adanya variabel independen. Pengembalian adalah keuntungan ataupun kerugian dari suatu investasi di dalam suatu periode yang didapatkan ataupun ditanggung oleh investor atas investasi yang dilakukan. Data yang digunakan adalah data closing price bulanan selama periode Februari 2012 sampai dengan Januari 2017. Data yang digunakan untuk pengembalian saham diperoleh dari penghitungan selisih harga saham individual periode berjalan dengan periode sebelumnya dengan menghiraukan dividen, dapat ditulis dengan rumus berikut : 
Stock Return $=\underline{\text { Harga } \text { saham periode }_{\mathrm{t}}-\text { Harga }_{\text {saham periode }} \mathrm{t}_{\mathrm{-}}}$

Harga saham periode $t-1$

Sumber: Oshaibat dan Majali (2016)

Variabel independen dalam penelitian ini sebagai berikut:

1. Inflasi

Salamat et al. (2017) menjelaskan bahwa inflasi adalah kenaikan tingkat harga secara keseluruhan. Tingkat inflasi diukur sebagai persentase perubahan dalam indeks harga konsumen (IHK), deflator PDB, atau indeks-indeks lain dalam harga keseluruhan. Dari penjelasan di atas inflasi didefinisikan sebagai tingkat kenaikan harga-harga produk dan jasa yang terdapat dalam suatu perkeonomian. Setiap negara memiliki tingkat inflasi yang berbeda-beda dan juga berbeda dari satu periode ke periode lainnya. Penurunan nilai mata uang domestik terhadap mata uang asing juga termasuk salah satu bentuk dari inflasi. Variabel inflasi diukur dengan mencatat laju inflasi indeks harga konsumen nasional yang diterbitkan Bank Indonesia tiap bulan.

2. Suku Bunga

Suku bunga didefinisikan sebagai pembayaran terhadap modal yang dipinjam dari pihak lain. Bunga biasanya dinyatakan sebagai persentasi dari modal yang dinamakan tingkat bunga. Persentase yang dinyatakan pada umumnya menunjukkan tingkat bunga dalam satu tahun (Safitri \& Kumar, 2014). Suku bunga dapat mempengaruhi laba perusahaan karena bunga merupakan biaya dan suku bunga juga mempengaruhi tingkat aktivitas ekonomi. Selain itu tingkat bunga yang tinggi merupakan sinyal negatif terhadap harga saham karena meningkatnya suku bunga juga menyebabkan investor menarik investasinya pada saham dan memindahkannya pada investasi berupa tabungan atau deposito (Kewal, 2012). Suku bunga yang digunakan dalam penelitian ini adalah tingkat suku bunga SBI atau Sertifikat Bank Indonesia yang merupakan surat berharga atas unjuk dalam rupiah yang diterbitkan oleh Bank Indonesia sebagai pengakuan utang berjangka waktu pendek dan diperjualbelikan dengan sistem diskonto. Suku bunga yang digunakan adalah rata-rata bulanan suku bunga SBI dari BI Rate dan BI 7day (Reverse) Repo Rate yang dipublikasikan Bank Indonesia.

3. Nilai tukar

Nilai tukar atau nilai tukar mengatakan bahwa nilai tukar (nilai tukar) adalah harga mata uang asing yang dinyatakan ke dalam mata uang negara asal (Murthy et al., 2017). Nilai tukar suatu mata uang dapat didefinisikan sebagai harga mata uang suatu negara terhadap mata uang negara asing lainnya. Nilai tukar mata uang akan selalu mengalami fluktuasi berdasarkan pada permintaan dan penawaran yang terjadi di pasar valuta asing. Nilai tukar atau kurs yang digunakan adalah kurs tengah rupiah terhadap dolar secara periodik 1 bulanan yang dipublikasikan Bank Indonesia. Berikut rumus pengukuran nilai tukar yang dapat dipakai:

Kurs Tengah $=($ Kurs Jual + Kurs Beli $) / 2$

Sumber: Murthy et al. (2017)

4. Harga Minyak Dunia

Harga minyak dunia adalah harga spot pasar minyak dunia yang mengalami fluktuasi oleh karena permintaan dan penawaran di pasar dunia. Pada penelitian ini harga minyak dunia, standar yang digunakan adalah standar Brent (Murthy et al., 2017). Data harga minyak dunia diambil dari www.fred.stlouisfed.org yang diterbitkan tiap akhir bulan (Marzouk, 2017). Harga minyak dunia yang berbentuk USD kemudian dikonversikan ke nilai Rupiah dengan menggunakan kurs tengah yang didapatkan di data nilai tukar.

5. Produk Domestik Bruto

Produk domestik bruto (PDB) didefinisikan sebagai nilai moneter barang dan jasa yang diproduksi di dalam suatu negara dalam jangka waktu tertentu. Laju pertumbuhan ekonomi suatu negara tercerminkan oleh tingkat produk domestik bruto di mana membaik bila ada kenaikan kapasitas produksi suatu perekonomian yang diwujudkan dalam bentuk kenaikan pendapatan nasional. Data produk domestik bruto yang digunakan produk domestik bruto harga konstan 2000 dan produk domestik bruto harga konstan 2010 dikarenakan tidak ada ketersediaan data PDB dalam bulanan maka data PDB diambil per kuarter dari PDB tiap kuarter yang diperoleh dari Badan Pusat Statistik.

6. Ekspor

Ekspor didefinisikan sebagai produk dan jasa yang diproduksi dalam negeri dan dijual ke luar negeri dengan tolak ukur mata uang asing (Hussain et al., 2014). Secara teori, bila nilai ekspor yang dikirim keluar ke negeri maka akan menaikkan profitabilitas dari suatu perusahaan sehingga akan menaikkan harga saham dari suatu perusahaan (Bellalah et al., 2012). Data ekspor yang digunakan adalah data 
bulanan mengenai jumlah keseluruhan nilai ekspor Indonesia dalam nilai USD yang didapatkan dari Badan Pusat Statistik. Nilai ekspor yang berbentuk USD kemudian dikonversikan ke nilai Rupiah dengan menggunakan kurs tengah yang didapatkan di data nilai tukar.

7. Impor

Impor diartikan pemasukan produk dan jasa dari luar negeri, seperti bahan baku, mesin, plantansi, barang jadi, dan berbagai produk yang digunakan untuk meningkatkan kinerja perusahaan dan kebutuhan suatu negeri. Ada berbagai hasil yang kontradiktif yaitu pengaruh positif dan negatif impor terhadap aktivitas ekonomi dan pengembalian saham dengan cara yang berbeda (Bellalah et al., 2012). Data impor yang digunakan adalah data bulanan mengenai jumlah keseluruhan nilai impor Indonesia dalam nilai USD yang didapatkan dari Badan Pusat Statistik. Nilai impor yang berbentuk USD kemudian dikonversikan ke nilai Rupiah dengan menggunakan kurs tengah yang didapatkan di data nilai tukar.

Penelitian ini menerapkan metode analisis regresi panel (panel regression analysis). Metode ini digunakan untuk mengembangkan sebuah model atau persamaan dan menguji pengaruh variable-variabel independen terhadap variabel dependen dengan skala pengukuran interval atau rasio. Data akan dilakukan pengujian statistik deskriptif, uji regresi panel untuk pemilihan model terbaik (uji chow dan uji hausman), dan uji hipotesis (uji F, uji t, dan Goodness of Fit Model) dengan menggunakan aplikasi perangkat lunak EViews (Econometric Views).

\section{HASIL PENELITIAN}

Penelitian ini menggunakan data sekunder dimana data-data tersebut diperoleh dari instansi yang menerbitkan data yang bersangkutan tentang data perusahaan yang terdaftar pada indeks LQ45 dalam periode Februari 2012 sampai Januari 2017 sebanyak 79 perusahaan. Data bulanan periode Februari 2012 sampai Januari 2017 perusahaan terdaftar di indeks LQ45 terdiri dari 2700 data.

Tabel 2 di bawah ini menunjukkan nilai minimum, maksimum, rata-rata, dan tingkat standar deviasi untuk tiap variabel yang ada pada sampel penelitian yaitu perusahaan yang terdaftar di LQ45 periode Februari 2012 - Januari 2017.

Tabel 2 Statistik Deskriptif

\begin{tabular}{lccccc}
\hline \multicolumn{1}{c}{ Variabel } & N & Minimum & Maximum & Mean & Std. Deviation \\
\hline Stock Return & 2700 & $-0,96$ & 0,6379 & 0,0058 & 0,1150 \\
Inflasi & 2700 & 0,0279 & 0,0879 & 0,0551 & 0,0176 \\
Suku Bunga & 2700 & 0,0475 & 0,775 & 0,0664 & 0,0095 \\
Nilai tukar & 2700 & 9,085 & 14,657 & 11,802 & 1,626 \\
Harga Minyak Dunia & 2700 & 426,502 & $1,348,513$ & 928,907 & 265,528 \\
(Rupiah) & & & & & \\
Produk Domestik Bruto & 2700 & 633,400 & $2,428,569$ & $1,647,646$ & 771,477 \\
(Miliar Rupiah) & 2700 & 126,350 & 206,820 & 163,482 & 15,473 \\
Ekspor (Miliar Rupiah) & 2700 & 118,070 & 189,848 & 160,830 & 15,435 \\
Impor(Miliar Rupiah) & & & &
\end{tabular}

Sumber: Data sekunderdiolah (2018)

Uji Chow dan uji Hausman digunakan untuk pemilihan model yang terakurat dan terbaik diantara pooled least square (PLS), fixed effect model (FEM), dan random effect model (REM). Uji Chow diterapkan untuk memilih antara model ordinary least square (OLS) tanpa variabel dummy atau fixed effect. Apabila nilai signifikan di bawah angka probabilitas alpha 0,05 maka dapat disimpulkan model regresi data panel dengan fixed effect model lebih baik. Hasil regresi uji Chow terhadap variabel dalam penelitian ditunjukan dalam Tabel 3

\begin{tabular}{lrrr}
\multicolumn{4}{c}{ Tabel 3 Hasil Uji Chow } \\
\hline Effects Test & Statistic & \multicolumn{1}{c}{ d.f. } & \multicolumn{1}{c}{ Prob. } \\
\hline Cross-section F & 1,772116 & $(78.2468)$ & 0,0000 \\
Cross-section Chi-square & 139,179529 & 78 & 0,0000 \\
\hline S
\end{tabular}

Sumber: Data sekunder diolah (2018) 
Tabel 3 memperlihatkan hasil uji yang disajikan dalam bentuk test cross section fixed effect dengan memperhatikan nilai probabilitas pada cross section chi-square. Nilai signifikansi sebesar 0,0000 atau lebih kecil dari 0,05, maka model teknik regresi panel dengan menggunakan fixed effect model tepat diterapkan untuk memprediksi variabel dependen.

Uji Hausman digunakan untuk memilih antara model fixed effect model (FEM) atau random effect model (REM). Apabila angka signifikan kurang dari angka probabilitas alpha 0,05 maka menggunakan model regresi data panel dengan fixed effect model. Hasil regresi uji Hausman terhadap variabel dalam penelitian disajikan dalam Tabel 4

Tabel 4 Hasil Uji Hausman

\begin{tabular}{lrrr}
\hline Test Summary & Chi-Sq. Statistic & Chi-Sq. d.f. & Prob. \\
\hline Cross-section random & 25,527691 & 7 & 0,0006
\end{tabular}

Sumber: Data sekunder diolah (2018)

Hasil uji Hausman yang disajikan menunjukkan probabilitas cross section random lebih kecil dari alpha 0,05 maka disimpulkan bahwa model yang tepat adalah fixed effect model. Uji $\mathrm{F}$ bermaksud untuk mencari tahu pengaruh variabel independen terhadap variabel dependen secara simultan. Hasil uji F pada data yang dilakukan dalam penelitian dapat dilihat pada Tabel 5 berikut ini:

\begin{tabular}{ccc} 
& Tabel 5 Hasil Uji F & \\
\hline Variabel Dependen & Sig. & Kesimpulan \\
\hline Pengembalian Saham & 0,000000 & Signifikan \\
\hline Sumber: Data sekunder diolah $(2018)$ & &
\end{tabular}

Sumber: Data sekunder diolah (2018)

Berdasarkan hasil pengujian Tabel 5 , nilai probabilitas yang didapatkan adalah 0,000000. Nilai tersebut lebih kecil daripada 0,05. Hasil tersebut memperlihatkan variabel independen berupa inflasi, suku bunga, nilai tukar, harga minyak dunia, produk domestik bruto, ekspor, dan impor memiliki pengaruh signifikan terhadap variabel dependen yaitu pengembalian saham secara simultan.

Uji t diterapkan untuk mengetahui pengaruh masing-masing variabel- variabel independen secara parsial. Hasil dari uji t dalam fixed effect model disajikan pada Tabel 6 di bawah ini:

Tabel 6 Hasil Uji t

\begin{tabular}{crrrcc}
\hline Variabel & Koefisien & t-Statistic & Prob. & Kesimpulan & Hipotesis \\
\hline C & 0.142438 & 4.194459 & 0.0000 & & \\
INF? & -0.962652 & -5.678014 & 0.0000 & Signifikan (-) & Terbukti \\
INT? & 2.010098 & 6.526341 & 0.0000 & Signifikan (+) & Tidak Terbukti \\
EXC? & $-1.77 \mathrm{E}-05$ & -4.643012 & 0.0000 & Signifikan (-) & Terbukti \\
OIL? & $2.53 \mathrm{E}-08$ & 1.730458 & 0.0837 & Tidak Signifikan & Tidak Terbukti \\
GDP? & $1.73 \mathrm{E}-08$ & 3.094797 & 0.0020 & Signifikan (+) & Terbukti \\
EXP? & $1.09 \mathrm{E}-15$ & 4.203711 & 0.0000 & Signifikan (+) & Terbukti \\
IMP? & $-1.52 \mathrm{E}-15$ & -6.901229 & 0.0000 & Signifikan (-) & Tidak Terbukti \\
\hline
\end{tabular}

Sumber: Data sekunder diolah (2018)

Persamaan regresi yang terbentuk berdasarkan hasil uji t pada Tabel 6 untuk model regresi adalah sebagai berikut:

$\mathrm{STR}_{\mathrm{it}}=0,142438-0,962652 \mathrm{INF}_{\mathrm{it}}+2,010098 \mathrm{INT}_{\mathrm{it}}-1,77 \mathrm{E}-05 \mathrm{EXC}_{\mathrm{it}}+2,53 \mathrm{E}-08 \mathrm{OIL}_{\mathrm{it}}+1,73 \mathrm{E}-$ $08 \mathrm{GDP}+1,09 \mathrm{E}-15 \mathrm{EXP}_{\mathrm{it}}-1,52 \mathrm{E}-15 \mathrm{IMP}_{\mathrm{it}} e_{\mathrm{it}}$

Hasil uji goodness of fit model diterapkan untuk mencari tahu seberapa besar pengaruh variabelvariabel independen dapat menjelaskan variabel dependen. Hasil uji goodness of fit model diperlihatkan pada Tabel 7 di bawah ini:

Tabel 7 Hasil Uji Goodness of Fit Model

\begin{tabular}{ccc}
\hline Variabel Dependen & $\boldsymbol{R}$ Square & Adjusted $\boldsymbol{R}$ Square \\
\hline Pengembalian Saham & 0,103304 & 0,072421 \\
\hline
\end{tabular}

Sumber: Data sekunder diolah (2018)

Hasil uji Tabel 7 menjelaskan kecocokan model yaitu pengaruh inflasi, suku bunga, nilai tukar, harga minyak dunia, produk domestik bruto, ekspor, dan impor terhadap pengembalian saham. Hasil uji goodness of fit model pada Tabel 7 di atas memperlihatkan bahwa adjusted $R$ square memiliki nilai sebesar 0,72421 yang menjelaskan bahwa variabel-variabel independen dapat menjelaskan sebesar 
7,2421\% terhadap variabel dependen dan $92.7579 \%$ dijelaskan oleh faktor-faktor lain yang tidak terdapat dalam model penelitian. Berdasarkan hasil uji, pembahasan hipotesis penelitian sebagai berikut:

$\mathrm{H}_{1}=$ Inflasi berpengaruh signifikan negatif terhadap stock return perusahaan yang terdaftar di LQ45.

Variabel inflasi memiliki koefisien regresi sebesar -0,962652 dengan nilai signifikansi 0.0000 dimana nilai ini lebih kecil dari 0,05 menunjukkan bahwa inflasi berpengaruh signifikan negatif terhadap variabel dependen atau pada pengembalian saham. Hasil ini terbukti dengan hipotesis yang menyatakan bahwa inflasi berpengaruh signifikan negatif terhadap pengembalian saham perusahaan yang terdaftar di LQ45. Hasil penelitian ini konsisten dengan penelitian yang dilakukan oleh Nisha (2015), Abbas et al. (2014), Haque dan Sarwar (2012). Namun penelitian ini tidak konsisten dengan penelitian yang dilakukan oleh Balagobei (2017), Tiryaki et al. (2017), Laichena dan Obwogi (2015), Pinjaman dan Aralas (2015), Kibria et al.(2014), Ouma dan Muriu (2014), Lekobane et al. (2014), dan Tangjitprom (2012).

Inflasi merupakan faktor yang dapat mempengaruhi arah pergerakan dari investasi yang berarti inflasi terdapat hubungan timbal balik antara risiko dan pengembalian saham dikarenakan oleh tingginya inflasi akan menaikkan harga barang dan jasa di pasar dimana secara langsung meningkatkan biaya suatu perusahaan dalam berbagai aspek. Bila biaya melebihi pendapatan perusahaan akan mengakibatkan penurunan pada profitabilitas suatu perusahaan. Penurunan profitabilitas akan menurunkan daya tariknya sehingga investor tidak tertarik untuk menginvestasi pada perusahaan tersebut. Hal ini mengakibatkan penurunan harga saham dan berdampak pada penurunan pengembalian saham (Haque \& Sarwar, 2012).

$\mathrm{H}_{2}=$ Suku bunga berpengaruh signifikan negatif terhadap stock returnperusahaan yang terdaftar di LQ45

Variabel suku bunga memiliki koefisien regresi sebesar 2,010098 dengan nilai signifikansi 0,0000 dimana nilai ini lebih kecil dari 0,05 menunjukkan bahwa suku bunga berpengaruh signifikan positif terhadap variabel dependen atau pengembalian saham. Hasil ini tidak terbukti dengan hipotesis yang menyatakan suku bunga berpengaruh signifikan negatif terhadap pengembalian saham perusahaan yang terdaftar di LQ45. Hasil ini konsisten dengan penelitian yang dilakukan oleh Nijam et al. (2015), Nisha (2015) dan Lim dan Sek (2014). Namun hasil ini tidak konsisten dengan Sutrisno (2017), Tiryaki et al. (2017), Balagobei (2017), Oshaibat dan Majali (2016), Latha et al. (2016), Linck dan Decourt (2016), Barakat et al. (2016), Laichena dan Obwogi (2015), Hussain et al. (2014), Haque dan Sarwar (2012),dan Tangjitprom (2012).

Menurut penelitian Lim dan Sek (2014) yang melakukan penelitian terhadap pengaruh nilai tukar terhadap pengembalian saham pada pasar saham di Indonesia, Korea, Filipina, dan Thailand berkesimpulan bahwa meningkatnya suku bunga akan menarik lebih investor luar negeri untuk menginvestasi dalam pasar perbankan sehingga nilai mata uang domestik meningkat nilainya yang mencerminkan juga langsung kepada pengembalian saham di pasar saham internasional.

$\mathrm{H}_{3}=$ Nilai tukar berpengaruh signifikan negatif terhadap pengembalian saham perusahaan yang terdaftar di LQ45

Variabel nilai tukar memiliki koefisien regresi sebesar -1,77E-05 nilai signifikansi 0,0000 dimana nilai ini lebih kecil dari 0,05 menunjukkan bahwa nilai tukar berpengaruh signifikan negatif terhadap pengembalian saham. Hasil ini terbukti mendukung hipotesis yang menyatakan nilai tukar berpengaruh signifikan negatif terhadap pengembalian saham perusahaan yang terdaftar di LQ45. Hasil ini konsisten dengan penelitian Srichaikul et al. (2018), Sutrisno (2017), Hussain et al. (2014), Lekobane et al. (2014), Safitri dan Kumar (2014), Tangjitprom (2012), Singh (2014), Ouma dan Muri (2014), Murthy et al. (2017), Laichena dan Obwogi (2015), dan Ramanujam dan Leela (2014). Namun hasil penelitian ini tidak konsisten dengan penelitian Balagobei (2017), Khan et al. (2017), Tiryaki et al. (2017), Nijam et al. (2015), Kibria et al. (2014), Pinjaman dan Aralas (2015), dan Nisha (2015).

Kenaikan nilai tukar dapat menurunkan persentase pengembalian saham, dikarenakan dengan depresiasi nilai uang domestik terhadap mata uang asing akan meningkatkan biaya-biaya bagi perusahaan seperti biaya impor dan juga yang lain sehingga memilik efek buruk pada profitabilitas perusahaan yang terdaftar di indeks LQ45 (Hussain et al. 2014). Dengan yang menguatnya kurs Dolar Amerika Serikat terhadap Rupiah Indonesia (IDR) yang mencapai angka Rp14.000/USD pada tahun 2015, ternyata menurunkan persentase pengembalian saham pada indeks LQ45 sebesar 17.73\% sepanjang tahun 2015. Hal ini akan menambah beban kepada perusahaan di LQ45 yang menggunakan bahan baku yang dibelikan dari luar negeri dan pembayaran dalam mata uang USD. 
$\mathrm{H}_{4}=$ Harga minyak dunia berpengaruh signifikan positif terhadap pengembalian saham perusahaan yang terdaftar di LQ45

Variabel harga minyak dunia memiliki koefisien regresi sebesar 2,53E-08 dengan nilai signifikansi 0,0837 dimana nilai ini lebih besar dari 0.05 menunjukkan bahwa harga minyak dunia tidak berpengaruh signifikan terhadap pengembalian saham. Hasil ini tidak terbukti mendukung hipotesis yang menyatakan harga minyak dunia berpengaruh signifikan positif terhadap pengembalian saham perus ahaan yang terdaftar di LQ45. Hasil penelitian ini konsisten dengan penelitian Srichaikul et al. (2018), Murthy et al. (2017), Gay (2016), Guliman dan Avenue (2015), dan Singh (2014). Namun hasil penelitian ini tidak konsisten dengan penelitian Tiryaki et al. (2017), Khan et al. (2016), Kang et al. (2014), dan Samontaray et al. (2014).

Perusahaan yang terdaftar pada indeks LQ45 selama periode Februari 2012 - Januari 2017 mayoritas adalah perusahaan yang tidak bergantung pada minyak untuk operasionalnya, sehingga tidak terdapat pengaruh secara langsung dari harga minyak dunia terhadap pengembalian saham indeks LQ45.

$\mathrm{H}_{5}=$ Produk domestik bruto berpengaruh signifikan positif terhadap pengembalian saham perusahaan yang terdaftar di LQ45

Variabel independen produk domestik bruto memiliki koefisien regresi sebesar 1,73E-08 dengan nilai signifikansi 0.0020 dimana nilai ini lebih kecil dari 0,05 menunjukkan bahwa produk domestik bruto berpengaruh signifikan positif terhadap pengembalian saham.Hasil ini terbukti mendukung hipotesis yang menyatakan produk domestik bruto berpengaruh signifikan positif terhadap pengembalian saham perusahaan yang terdaftar di LQ45. Hasil penelitian ini konsisten dengan penelitian Linck dan Decourt (2016), Ismail et al. (2016), Laichena dan Obwogi (2015), Nijam et al. (2015), Lekobane et al. (2014), Ramanujam dan Leela (2014), Monjazeb dan Gohari (2013), Kibria et al. (2014), serta Haque dan Sarwar (2012). Namun hasil penelitian ini tidak konsisten dengan penelitian Salamat et al. (2017), Pinjaman dan Aralas (2015), Abbas et al. (2014), dan Safitri dan Kumar (2014).

Produk domestik bruto yang semakin meningkat mengartikan bahwa pertumbuhan ekonomi sedang berkembang dikarenakan berbagai aktifitas perusahaan yang bekerja dengan maksimal dan menghasilkan profit sehingga pembagian dividen dari perusahaan ke para investor akan lebih lancar yang menyebabkan investor tertarik untuk membeli saham perusahaan tersebut. Dengan banyaknya investasi yang masuk menyebabkan harga saham naik dan juga pengembalian saham yang bertambah.

$\mathrm{H}_{6}=$ Ekspor berpengaruh signifikan positif terhadap pengembalian saham perusahaan yang terdaftar di

LQ45

Variabel ekspor memiliki koefisien regresi sebesar 1,09E-15 dengan nilai signifikansi 0,0000 dimana nilai ini lebih kecil dari 0,05 menunjukkan bahwa ekspor berpengaruh signifikan positif terhadap pengembalian saham. Hasil ini terbukti mendukung hipotesis yang menyatakan ekspor berpengaruh signifikan positif terhadap pengembalian saham perusahaan yang terdaftar di LQ45. Hasil penelitian ini konsisten dengan Monjazeb dan Gohari (2013), Hussain et al. (2014) serta Samontaray et al. (2014). Namun hasil penelitian ini tidak konsisten dengan Zhu (2012) dan Bellalah et al. (2012).

Semakin banyak pertambahan pada jumlah ekspor maka akan meningkatkan profitabilitas perusahaan yang berbasis ekspor sehingga pembagian dividen dari perusahaan tersebut akan bertambah dan berdampak positif terhadap harga saham dari perusahaan tersebut dan meningkatkan pengembalian saham yang akan diterima.

$\mathrm{H}_{7}=$ Impor berpengaruh signifikan positif terhadap pengembalian saham perusahaan yang terdaftar di LQ45

Variabel impor memiliki koefisien regresi sebesar -1,52E-15 dengan nilai signifikansi 0,0000 dimana nilai ini lebih kecil dari 0.05 menunjukkan bahwa impor berpengaruh signifikan negatif terhadap pengembalian saham. Hasil ini terbukti tidak mendukung hipotesis yang menyatakan impor berpengaruh signifikan positif terhadap pengembalian saham perusahaan yang terdaftar di LQ45. Hasil penelitian ini tidak konsisten dengan Monjazeb dan Gohari (2013), Hussain et al. (2014) serta Samontaray et al. (2014), Zhu (2012) dan Bellalah et al. (2012).

Semakin meningkatnya nilai impor dapat mengartikan bahwa banyak bahan baku untuk produksi harus didapatkan dari luar negeri dengan biaya yang lebih mahal sehingga membebankan biaya dari perusahaan yang bersangkutan dan dapat menurunkan profitabilitas dari perusahaan tersebut. Hal ini akan menyebabkan pengurangan dalam pembagian dividen dimana akan mempengaruhi ketertarikan investor terhadap saham tersebut dan mengakibatkan penurunan pengembalian saham. 


\section{KESIMPULAN}

Berdasarkan hasil analisis data, hasil penelitian ini menunjukkan bahwa suku bunga, produk domestik bruto, dan ekspor akan meningkatkan stock return pada perusahaan yang indeks saham LQ45. Variabel inflasi, nilai tukar, dan impor berpengaruh negatif terhadap stock return. Hasil penelitian juga menunjukkan harga minyak dunia tidak memiliki pengaruh terhadap stock return.

\section{DAFTAR PUSTAKA}

Abbas, S., Tahir, S. H., \& Raza, S. (2014). Impact of Macroeconomic Variables on Stock Returns : Evidence from KSE-100 Index of. The International's Research Journal of Economics \& Business Studies, 3(7), 70-77.

Ajija, S. R. (2011). Cara Cerdas Menguasai EViews. Jakarta: Salemba Empat.

Astuti, R., Lapian, J., \& Rate, P. Van. (2016). Pengaruh Faktor Makro Ekonomi Terhadap Indeks Harga Saham Gabungan (IHSG) di Bursa Efek Indonesia (BEI) Periode 2006-2015. Jurnal Berkala Ilmiah Efisiensi, 16(2), 399-406.

Balagobei, S. (1946). Macroeconomic Variables and Stock Market Returns in Sri Lanka. Asian Journal of Finance \& Accounting, 9(2), 206-218. https://doi.org/10.5296/ajfa.v9i2.11832

Bank Indonesia. (2017). Informasi Kurs. Retrieved from https://www.bi.go.id/id/moneter/informasikurs/transaksi-bi/Default.aspx

Barakat, M. R., Elgazzar, S. H., \& Hanafy, K. M. (2016). Impact of Macroeconomic Variables on Stock Markets: Evidence from Emerging Markets. International Journal of Economics and Finance, 8(1), 195-207. https://doi.org/10.5539/ijef.v8n1p195

Bellalah, M., Masood, O., Darshini, P., Thapa, P., Levyne, O., \& Triki, R. (2012). Economic Forces and Stock Exchange Prices: Pre and Post Impacts of Global Financial Recession of 2008. Journal of Computations \& Modelling, 2(2), 157-179.

Dakwatuna. (2015). Melihat Lebih Dalam Krisis Ekonomi Indonesia. Retrieved from https://www.dakwatuna.com/2015/08/18/73289/melihat-lebih-dalam-krisis-ekonomi-indonesia2015/\#axzz59bUdBuFZ

Gay, R. D. (2016). Effect Of Macroeconomic Variables On Stock Market Returns For Four Emerging Economies: Brazil, Russia, India, And China. International Business \& Economics Research Journal, 15(3), 1363-1372. Retrieved from http://www.cluteonline.com/journals/index.php/IBER/article/view/3229

Ghozali, I. (2013). Aplikasi Analisis Multivariat dengan Program IBM SPSS 21. Edisi 7, Semarang: Penerbit Universitas Diponegoro.

Guliman, S. D. O. (2015). Oil Prices and Stock Market: A Philippine Perspective. Business and Economic Research, 5(2), 122. https://doi.org/10.5296/ber.v5i2.7941

Haque, A., \& Sarwar, S. (2012). Macro-Determinants of Stock Return in Pakistan. Middle-East Journal of Scientific Research, 12(4), 504-510. https://doi.org/10.5829/idosi.mejsr.2012.12.4.1650

Hussain, M.M, Aamir, M., Rasool, N., Fayyaz, M., Mumtaz, M. (2014). The Impact of Macroeconomic Variables on Stock Prices: An Empirical Analysis of Karachi Stock Exchange. Mediterranean Journal of Social Sciences, 3(October), 295-312. https://doi.org/10.5901/mjss.2012.v 3n3p295

Ibrahim, T. M., \& Agbaje, O. M. (2013). The Relationship Between Stock Return And Inflation In Nigeria. European Scientific Journal, 9(4), 146-157.

Indriantoro, N \& Supomo, B. (2013). Metodologi Penelitian Bisnis untuk Akuntansi dan Manajemen. Yogyakarta: Fakultas Ekonomika dan Bisnis UGM.

Ismail, R., Pervaz, A., Ahmed, A., \& Iqbal, R. (2016). Macroeconomic Factors and the Pakistani Equity Market : A Relationship Analysis. International Journal of Innovation and Applied Studies, 15(1), $122-129$.

Jamil, M., \& Ullah, N. (2013). Impact of Foreign Exchange rate on stock prices. IOSR Journal of Business and Management, 7(3), 45-51.

Kang, W., Ratti, R. A., \& Yoon, K. H. (2015). The Impact of Oil Price Shocks on The Stock Market Return and Volatility Relationship. Journal of International Financial Markets, Institutions and Money, 34, 41-54. https://doi.org/10.1016/j.intfin.2014.11.002

Kewal, S. S. (2012). Pengaruh Inflasi, Suku Bunga, Kurs, dan Pertumbuhan PDB Terhadap Indeks Harga Saham Gabungan. Jurnal Economia, Vol.8, No.1. 
Khan, A., Naseem, I., \& Khan, M. K. (2016). Relationship of International Oil Prices , Gold Prices and Stock Returns; Evidence from KSE. International Conference on Emergin Research for Sustainable Economic Development, 1-22.

Khan, M. K., Teng, J.-Z., Parvaiz, J., \& Chaudhary, S. K. (2017). Nexuses between Economic Factors and Stock Returns in China. International Journal of Economics and Finance, 9(9), 182-191. https://doi.org/10.5539/ijef.v9n9p182

Kibria, U., Mehmood, Y., Kamran, M., Arshad, M. U., Perveen, R., \& Sajid, M. (2014). The Impact of Macroeconomic Variables on Stock Market Returns : A Case of Pakistan. Research Journal of Management Science, 3(8), 1-7.

Laichena, K. E., \& Obwogi, T. N. (2015). Effects of Macroeconomic Variables on Stock Returns in The East African Community Stock Exchange Market. International Journal of Education and Research, 3(10), 304-320.

Latha, K., Gupta, S., \& Ghosh, R. (2016). Interest Rate Sensitivity of Stock Returns: A Case Study of Textile Sector in India. Asian Journal of Multidisciplinary Studies, 4(4), 56-61. Retrieved from www.ajms.co.in

Lekobane, K. R., \& Lekobane, O. L. S. (2014). Do Macroeconomic Variables Influence Domestic Stock Market Price Behaviour in Emerging Markets? A Johansen Cointegration Approach to the Bots wana Stock Market. Journal of Economics and Behavioral Studies, 6(5), 363-372.

Lim, S. Y., \& Sek, S. K. (2014). Exploring the Inter-relationship between the Volatilities of Exchange Rate and Stock Return. Procedia Economics and Finance, 14(14), 367-376. https://doi.org/10.1016/S2212-5671(14)00725-4

Linck, L., \& Decourt, R. F. (2016). Stock Returns, Macroeconomic Variables and Expectations: Evidence from Brazil. Pensamiento \& Gestión, 40, 91-112.

Martalena \& Malinda, M. (2011). Pengantar Pasar Modal. Edisi Pertama. Yogyakarta: Andi

Marzouk, O. A. (2017). In the Aftermath of Oil Prices Fall of 2014 / 2015 - Socioeconomic Facts and Changes in the Public Policies in the Sultanate of Oman. International Journal of Management and Economics Invention, 3(11), 1463-1479. https://doi.org/10.18535/ijmei/v3i11.09

May, E. (2017). Saham Blue Chip dan Indeks LQ. Retrieved from https://www.ellenmay.com/v3/s aham-blue-chip-dan-indeks-lq-45/

Merdeka. (2015). Tak hanya Shell, Perusahaan Minyak Italia Juga Pecat 8.800 Pekerja. Retrieved from https://www.merdeka.com/uang/tak-hanya-shell-perusahaan-minyak-italia-juga-pecat-8800pekerja.html

Monjazeb, M., \& Gohari, H. H. (2013). Impact of Oil Exports Income on Tehran Stock Exchange Dividend and Price Index (TEDPIX), Model Selection. World Applied Sciences Journal, 22(6), 819-823. https://doi.org/10.5829/idosi.wasj.2013.22.06.210

Murthy, U., Anthony, P., \& Vighnesvaran, R. (2016). Factors Affecting Kuala Lumpur Composite Index (KLCI) Stock Market Return in Malaysia. International Journal of Business and Management, 12(1), 122-132. https://doi.org/10.5539/ijbm.v12n1p122

Nijam, H., Ismail, S., \& Musthafa, A. (2015). The Impact of Macro-Economic Variables on Stock Market Performance; Evidence From Sri Lanka. Journal of Emerging Trends in Economics and Management Sciences, 6(2), 151-157.

Nisha, N. (2015). Impact of Macroeconomic Variables on Stock Returns: Evidence from Bombay Stock Exchange (BSE). Journal of Investment and Management, 4(5), 162 https://doi.org/10.11648/j.jim.20150405.14

Oshaibat, S. Al. (2016). The Relationship Between Stock Returns and Each of Inflation , Interest Rates , Share Liquidity and Remittances of Workers in the Amman Stock Exchange. Journal of Internet Banking and Commerce, 21(2), 1-18.

Ouma, W. N., \& Muriu, P. (2014). The Impact of Macroeconomic Variables on Stock Market Returns in Kenya. International Journal of Business and Commerce, 3(11), 1-31.

Pinjaman, S. Bin, \& Aralas, S. B. (2015). The Dynamic Stock Returns Volatility and Macroeconomic Factors in Malaysia: A Sectoral Study. South East Asia Journal of Contemporary Business, Economics and Law, 8(3), 33-40.

Ramanujam, V., \& Leela, L. (2014). The Effect of Macroeconomic Variables on Stock Prices in Emerging Stock Market: Empirical Evidence From India. Indian Journal of Applied Research, 4(6), $1-4$. 
DetikNews. (2016). Pertumbuhan Ekonomi RI Sangat Bergantung ke China. Retrieved January 15, 2018, from https://finance.detik.com/berita-ekonomi-bisnis/d-3233101/pertumbuhan-ekonomi-ri-s angatbergantung-ke-china

Safitri, I. R., \& Kumar, S. (2014). The Impact Of Interest Rates , Inflation , Exchange Rates And Gdp On Stock Price Index Of Plantation Sector: Empirical Analysis On BEI In The Year Of 2008 - 2012. International Conference on Trends in Multidisciplinary Business and Economics Research, 1, 5561.

Salamat, W. Al, Masadeh, W., \& Mansour, E. (2016). Macroeconomics, Firm-Specific Factors and Excess Return: An Empirical Investigation from Amman Stock Exchange. Global Journal of Business Research, 10(4), 1-16.

Samontaray, D. P., Nugali, S., \& Sasidhar, B. (2014). A Study of the Effect of Macroeconomic Variables on Stock Market : Saudi Perspective. International Journal of Financial Research, 5(4), 120-127. https ://doi.org/10.5430/ijfr.v5n4p 120

Santoso, S. (2012). Panduan Lengkap SPSS Versi 20. Jakarta: PT Elex Media Komputindo.

Sindonews. (2016). Harga Minyak Dunia Merosot. Retrieved from https://ekbis.sindonews.com/read/1073747/35/harga-minyak-dunia-merosot-35-sepanjang-20151451619398

Singh, P. (2014). An Empirical Relationship Between Selected Indian Stock Market Indices and Macroeconomic Indicators. International Journal of Research in Business Management, 2(9), 8192. Retrieved from www.impactjournals.us

Srichaikul, W., Yamaka, W., \& Tansuchat, R. (2018). The Impacts of Macroeconomic Variables on Financials Sector and Property and Construction Sector Index Returns in Stock Exchange of Thailand Under Interdependence Scheme. Predictive Econometrics and Big Data, 753, 590-599. https://doi.org/10.1007/978-3-319-70942-0_42

Sugiyono. (2012). Metode Penelitian Bisnis. Bandung: Alfabeta.

Sutrisno, B. (2017). Macroeconomic Variables and Sectoral Indices: Case in The Indonesia Stock Exchange. Etikonomi, 16(1), 71-80. https://doi.org/10.15408/etk.v16i1.4323

Tangjitprom, N. (2012). Macroeconomic Factors of Emerging Stock Market: The Evidence from Thailand. International Journal of Financial Research, 3(2), 105-114. https://doi.org/10.5430/ijfr.v3n2p 105

Tiryaki, A., Erdoğan, L., \& Ceylan, R. (2017). The Causal Relationship Between Selected Macroeconomic Variables and Stock Returns in Turkey. Uluslararasi İktisadi ve İdari Incelemeler Dergisi, 19, 299-326. https://doi.org/10.18092/ulikid ince.309275

Tripathi, V., \& Kumar, A. (2014). Relationship between Inflation and Stock Returns - Evidence from BRICS markets using Panel Co integration Test. International Journal of Accounting and Financial Reporting, 4(2), 647-658. https://doi.org/10.5296/ijafr.v4i2.6671

YahooFinance. (2017). IHSG Monthly Closing Price. Retrieved from https://finance.yahoo.com/quote/\%5EJKSE/history?period $1=1325350800 \&$ period $2=1483117200 \& \mathrm{i}$ nterval $=1$ mo $\&$ filter $=$ his tory $\&$ frequency $=1 \mathrm{mo}$

Zhu, B. (2012). The Effects of Macroeconomic Factors on Stock Return of Energy Sector in Shanghai Stock Market. International Journal of Scientific and Research Publications, 2(11), 1-4. Retrieved from www.ijsrp.org 